\title{
Expression of $c$-kit in fibroepithelial lesions of the breast is a mast cell phenomenon
}

\author{
Bojana Djordjevic and Wedad M Hanna \\ Department of Pathology, Sunnybrook and Women's College Health Sciences Centre, University of Toronto, \\ Toronto, ON, Canada
}

\begin{abstract}
The expression of $c$-kit, a protooncogene tyrosine kinase receptor (CD117), in phyllodes tumors of the breast has been the subject of recent investigations. We examined stromal c-kit expression by immunohistochemistry in 68 cases comprising fibroadenomas, fibroadenomas with cellular stroma, and benign, borderline, and malignant phyllodes tumors. Membrane staining was identified in the epithelium of $82 \%$ of cases, representing all diagnostic categories in the study. Membrane and cytoplasmic staining was detected in scant cells in the stroma in $74 \%$ of the cases in the study, again, across all diagnostic entities. However, when toluidine blue and tryptase staining was performed, the staining pattern matched that of c-kit in the number of cells and their distribution, thereby confirming the presence of mast cells and excluding any appreciable level of true stromal c-kit staining. One borderline and one malignant phyllodes tumor showed a diffuse weak stromal signal, which could not be accounted for by toluidine blue and tryptase. These cases were further tested for the presence of known activating mutations of $c-k i t$ and $P D G F R-\alpha$, and yielded negative results. Our findings indicate that $c-k i t$ is an unlikely player in the pathogenesis of fibroepithelial lesions of the breast. The positive stromal staining suggested previously by other authors may be attributed to mast cells. $\boldsymbol{C}$-kit, therefore, has neither a diagnostic nor a prognostic role in phyllodes tumors, and there is no rationale for the treatment of recurrent of malignant phyllodes tumor patients with tyrosine kinase inhibitors.
\end{abstract}

Modern Pathology (2008) 21, 1238-1245; doi:10.1038/modpathol.2008.78; published online 23 May 2008

Keywords: c-kit; CD117; fibroepithelial lesion; phyllodes; fibroadenoma; mast cell

Phyllodes tumors represent $0.3-1 \%$ of all primary tumors and $2.5 \%$ of fibroepithelial tumors of the breast. They are purported to develop de novo from intralobular or periductal stroma or to arise from fibroadenomas. ${ }^{1}$ Based on a number of criteria, phyllodes tumors can be classified into benign, borderline, or malignant.

C-kit (CD117) is a protooncogene that encodes a transmembrane tyrosine kinase growth factor receptor. Through interaction with its ligand, stem cell factor, the c-kit protein plays a role in hematopoiesis, melanogenesis, gametogenesis, and other normal physiological functions. ${ }^{2}$ Mutations at several different sites (exons 9, 11, 13 and $17^{3,4}$ ) of the $c$-kit gene cause constitutive activation of the tyrosine kinase function of the c-kit protein. These mutations result in autophosphorylation of the c-kit protein, ligand-independent tyrosine kinase activity, uncontrolled cell proliferation, and stimulation of down-

Correspondence: Dr W Hanna, MD, Sunnybrook Health Sciences Centre, 2075 Bayview Ave., Room E4 32, Toronto, ON M4N 3M5, Canada.

E-mail: wedad.hanna@sunnybrook.ca

Received 11 December 2007; revised 21 March 2008; accepted 24 March 2008; published online 23 May 2008 stream signaling. ${ }^{2,5,6} \mathrm{C}$-kit has been implicated in the tumorigenesis of a variety of neoplasms including gastrointestinal stromal tumors (GISTs), small cell lung carcinomas, melanoma, and breast carcinoma. ${ }^{7-9}$ Imatinib mesylate (Glivec internationally, Gleevec in the United States $)^{10,11}$ is a tyrosine kinase inhibitor and is used to treat GISTs that express $C$ kit. $^{12}$ In $5-10 \%$ of GISTs that are $c$-kit mutation negative, mutations in another gene, platelet-derived growth receptor- $\alpha$ (PDGFR $\alpha$; exons 12, 14, and 18), have been identified. ${ }^{13,14}$ PDGFR $\alpha$ protein belongs to the same transmembrane receptor tyrosine kinase family (type III) as the c-kit protein, and binds platelet-derived growth factor. Interestingly, $c$-kit and PDGFR $\alpha$ mutations are mutually exclusive in GISTs. ${ }^{10}$ It has been shown that different types of $c$-kit and PDGFR $\alpha$ mutations each correspond to a different response to imantinib. ${ }^{4}$

The original rationale for looking at c-kit expression in phyllodes tumor arose out of its similarities with GIST. Both tumors share certain characteristics such as spindled, CD34-positive stromal cells, and show a spectrum of behavior from benign to malignant. ${ }^{15}$ In addition, past studies have demonstrated consistent expression of $c$-kit in breast epithelium, variable expression in benign 
breast lesions, and poor expression in breast carcinoma. ${ }^{2} \mathrm{~A}$ few recent investigations that have looked at $c$-kit expression in phyllodes tumors have had varying results. ${ }^{3,15-19}$ Accurate assessment of the level of expression of $c$-kit, and further elucidation of the role it may play in the tumorigenesis of phyllodes tumors is an essential first step in determining the potential effectiveness of imatinib mesylate as a therapeutic agent of phyllodes tumors. The aim of this project was to study the expression of $c$-kit in fibroepithelial lesions of the breast.

\section{Materials and methods}

Two institutions (Sunnybrook Health Sciences Center, Toronto, ON, Canada and Markham Stouffville Hospital, Markham, ON, Canada) participated in our study. We searched for cases that occurred between the years of 1991 and 2004 in our databases using the following terms: 'fibroadenoma', 'fibroadenoma with cellular stroma', 'phyllodes tumor,' and 'cystosarcoma phyllodes'. This search method retrieved a group of mastectomy, lumpectomy and biopsy specimens all from female patients. When more than one specimen was identified from the same patient (ie, biopsy and mastectomy), only the specimen with the greatest amount of tissue (ie, mastectomy) was included in the study.

We defined cellular fibroadenomas as lesions of the usual fibroadenoma morphology, but with an increased stromal cellularity. Entities such as juvenile fibroadenoma and giant cell fibroadenoma were included in this category. We used stromal expansion and the low-power leaf-like architecture as the main distinguishing feature between phyllodes tumors and fibroadenomas. The grade of the phyllodes tumors was assessed by the following criteria: (1) mitotic count, (2) nuclear pleomorphism, (3) stromal cellularity (4) infiltrating border (5) necrosis, and (6) stromal overgrowth. Mitotic count of $<2$ mitoses, 2-5 mitoses, and $>5$ mitoses per $10 \mathrm{HPFs}$ $(\times 40)$ was recorded. Nuclear pleomorphism and stromal cellularity were graded as low, moderate, and high. Infiltrating border and necrosis were assessed to be present or absent. Stromal overgrowth was judged to be present, if there were areas of tumor at $\times 40$ that were devoid of stromal elements. A phyllodes tumor considered to be malignant would have had a mitotic count of $>5 / 10 \mathrm{HPF}$, high nuclear pleomorphism, and stromal cellularity, necrosis, an infiltrating border, and stromal overgrowth. A benign phyllodes tumor would have a mitotic count of $<2 / 10 \mathrm{HPF}$, low-stromal cellularity, low-to-absent nuclear pleomorphism, a pushing border, no necrosis, and no stromal overgrowth. A borderline phyllodes tumor would meet some, but not all criteria for a malignant phyllodes tumor. The grading was performed in a blinded fashion by the investigator $\mathrm{BD}$ and cross referenced with the original diagnosis. Discrepant cases were reviewed by the investigator WH. Four (minor) diagnostic discrepancies were resolved in favor of the original diagnoses.

A representative slide for of each tumor was selected. The corresponding paraffin blocks were cut to yield $4 \mu \mathrm{m}$ slides. Automated immunohistochemistry for c-kit was performed (Dako Autostainer) using heat-induced epitope retrieval (Borg $\mathrm{pH}$ 9.5 buffer) in a pressure cooker for $2 \mathrm{~min}$ at $120^{\circ} \mathrm{C}$. The slides were then treated for $1 \mathrm{~h}$ with the monoclonal c-kit antibody (Zymed; 1:400 dilution), followed by detection with a polymer system (Biocare Mach 3 Polymer) according to the systemprescribed protocol.

The stromal elements of each tumor were assessed for staining intensity and then for the percentage of c-kit-staining stromal cells. A stromal signal was considered positive, if it displayed equal or greater intensity than that that of the benign breast epithelium in the surrounding tissue. If latter was not present in the section, comparison was made with the benign breast epithelium in the positive immunohistochemical control. The percentage scoring categories were defined as $0,<5 \%$ and $>5 \%$ of stromal cells. As mast cells are positive for c-kit, ${ }^{20,21}$ mast cell-rich tumors were also stained with toluidine blue and tryptase, so that the levels of true stromal c-kit staining may be determined. Equivocal cases underwent $c$-kit and PDGFR $\alpha$ mutational analysis. The epithelial component of all fibroepithelial lesions was also observed for the intensity and then for the percentage of cells staining with c-kit. The criteria for both parameters were the same as for the stromal component. Scoring of stromal and epithelial immunostaining was performed by the investigator $\mathrm{BD}$; stromal to mast cell c-kit staining correlation for all cases, as well as the evaluation of all equivocal stromal c-kit-staining cases was carried out by investigators BD and WH.

Toluidine blue staining was performed with a $1 \%$ toluidine blue solution, and by differentiation in $3 \%$ acetic acid. Tryptase immunohistochemistry was carried out using a standard streptavidin-biotinperoxidase. Endogenous peroxidase and biotin activities were blocked using $3 \%$ aqueous hydrogen peroxide and an avidin-biotin blocking kit (Lab Vision). Sections were pretreated with pepsin for $15 \mathrm{~min}$ at $37^{\circ} \mathrm{C}$ and then blocked with normal horse serum before incubating for $1 \mathrm{~h}$ with mouse antihuman mast cell tryptase (Chemicon) at $1 / 500$. Color development was performed using freshly prepared Novared solution (Vector Labs).

The mutational analysis included preparation of tumor tissue DNA from formalin-fixed, paraffinembedded specimens by using proteinase K (Invitrogen, Germany) digestion according to standard protocol. ${ }^{22}$ Exons 9, 11, 13, and 17 of the $c$-kit gene and exons 12 and 18 of the PDGFR $\alpha$ gene were amplified by PCR. The primer sequences for PCR are summarized in Table $1 .^{14,23-26}$ Annealing temperature was $60^{\circ} \mathrm{C}$ for all of primers. The PCR products 
were purified by filtration (Millipore Co.) and then directly sequenced using the same forward and reverse primers. The sequencing was performed using Big Dye Termination reaction mix V1.1 and an automated genetic analyzer (ABI PRISM® 3100; Applied Biosystems, Foster City, CA, USA) based on fluorescence detection and capillary electrophoresis.

\section{Results}

There were 68 cases in our study consisting of 18 biopsy and 50 lumpectomy and mastectomy cases. The various tumor types were represented as follows (Table 2): 12 fibroadenomas, nine cellular fibroadenomas, 30 benign phyllodes tumors, 10 borderline phyllodes tumors, and seven malignant phyllodes tumors.

Membrane and cytoplasmic staining for c-kit was detected in cells in the stroma of $74 \%$ of the cases in the study (Table 3). This group was represented by seven fibroadenomas, eight fibroadenomas with cellular stroma, 22 benign phyllodes, seven borderline phyllodes, and six malignant phyllodes tumors. The cells that were staining were round to oval, always scattered throughout the tumor, and were never found in groups. Only five cases exceeded the

Table 1 Primer sequences for amplification of exons 9, 11, 13, and 17 of $c$-kit gene and exons 12 and 18 of PDGFR $\alpha$ gene by PCR $(\mathrm{F}=$ forward primer; $\mathrm{R}=$ reverse primer $)$

\begin{tabular}{|c|c|c|}
\hline Exon & $\begin{array}{l}\text { Primer sequence } \\
\left(5^{\prime} \rightarrow 3^{\prime}\right)\end{array}$ & $\begin{array}{l}\text { Fragment } \\
\text { length (bp) }\end{array}$ \\
\hline \multirow[t]{2}{*}{9} & F: ATTTATTTTCCTAGAGTAAGCCAGGG & \\
\hline & R: ATCATGACTGATATGGTAGACAGAGC & 305 \\
\hline \multirow[t]{2}{*}{11} & F: CCAGAGTGCTCTAATGACTG & \\
\hline & R: ACTCAGCCTGTTTCTGGGAAACTC & 191 \\
\hline \multirow[t]{2}{*}{13} & F: GCTTGACATCAGTTTGCCAG & \\
\hline & R: AAAGGCAGCTTGGACACGGCTTTA & 192 \\
\hline \multirow{2}{*}{17} & F: TGAACATCATTCAAGGCGTACTTTTG & \\
\hline & R: TTGAAACTAAAAATCCTTTGCAGGAC & 348 \\
\hline \multirow[t]{2}{*}{12} & F: TCCAGTCACTGTGCTGCTTC & \\
\hline & R: GCAAGGGAAAAGGGAGTCTT & 260 \\
\hline \multirow[t]{2}{*}{18} & F: ACCATGGATCAGCCAGTCTT & \\
\hline & R: GTGTGGGAAGTGTGGACGTA & 230 \\
\hline
\end{tabular}

$>5 \%$ benchmark, but did not exceed $10 \%$ (results not shown), while the positive-staining cells maintained the dispersed pattern. When c-kit staining in these tumors was compared with that of toluidine blue and tryptase, cells with a similar distribution were highlighted, thus confirming the presence of mast cells and suggesting that there was no true stromal c-kit signal (Figures 1 and 2).

Two cases in the study, one borderline and one malignant phyllodes tumor, showed a more diffuse stromal-staining pattern, which could not be accounted for by toluidine blue and tryptase, involving elongated stromal cells. The intensity of c-kit staining in these cells was less than what would be considered positive by our criteria (Figure 3). Nevertheless, these two cases underwent molecular analysis and were found to be negative for $c$-kit and $P D G F R \alpha$ mutations. In summary, none of the 68 fibroepithelial lesions in our study, with 47 lesions representing phyllodes tumors, displayed true stromal staining for c-kit.

As a p-value cannot be calculated for a single population, we used a single proportion estimate method to determine the significance of our findings. With a $95 \%$ confidence interval, and a sample size of 47 phyllodes tumors, a single proportion value of $\leq 0.094$ is significant $(>0.05)$. As our single proportion value is zero (0/47), our finding is therefore significant. For comparison, if 1 out of 47 cases had shown true stromal staining for c-kit, the single proportion value would have been $0.021(1 / 47)$, which is $\leq 0.094$ and therefore also would have been significant.

Table 2 Number and distribution of cases in the study

\begin{tabular}{|c|c|c|c|}
\hline Tumor type & $\begin{array}{c}\text { Lumpectomies } \\
\text { and } \\
\text { mastectomies }\end{array}$ & Biopsies & Total \\
\hline
\end{tabular}

\begin{tabular}{lrrr}
\hline Fibroadenoma & 6 & 6 & 12 \\
Cellular fibroadenoma & 4 & 5 & 9 \\
Benign phyllodes & 26 & 4 & 30 \\
Borderline phyllodes & 8 & 2 & 10 \\
Malignant phyllodes & 6 & 1 & 7 \\
Total & 50 & 18 & 68
\end{tabular}

Table 3 Number and staining distribution of cases with a stromal c-kit signal. This signal was subsequently attributed to mast cells in the stroma, following toluidine blue and tryptase staining

\begin{tabular}{|c|c|c|c|c|c|}
\hline \multirow[t]{2}{*}{ Tumor type } & \multicolumn{4}{|c|}{ Raw case numbers } & \multirow[t]{2}{*}{ Percentage of all positive ( $<5 \%$ and $>5 \%$ ) cases } \\
\hline & 0 & $<5 \%$ & $>5 \%$ & Total & \\
\hline Fibroadenoma & 5 & 6 & 1 & 12 & $58 \%$ \\
\hline Cellular fibroadenoma & 1 & 6 & 2 & 9 & $89 \%$ \\
\hline Benign phyllodes & 8 & 21 & 1 & 30 & $73 \%$ \\
\hline Borderline phyllodes & 3 & 6 & 1 & 10 & $70 \%$ \\
\hline Malignant phyllodes & 1 & 6 & 0 & 7 & $86 \%$ \\
\hline Total & 18 & 45 & 5 & 68 & $74 \%$ \\
\hline
\end{tabular}



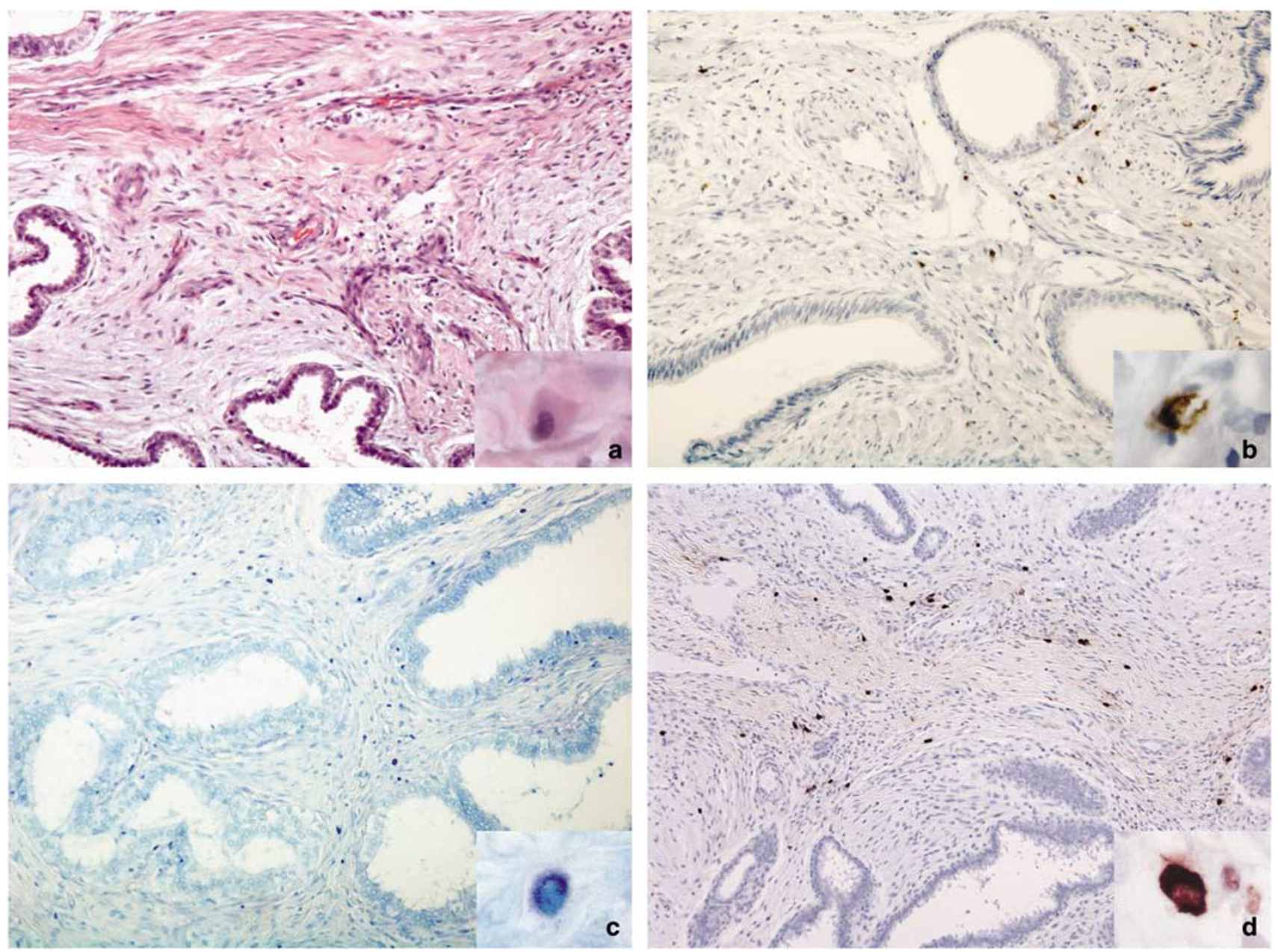

Figure 1 Benign phyllodes tumor with mast-cell infiltration of the stroma on H\&E (a). C-kit immunohistochemical staining reveals a pattern of scattered round to oval cells in the stroma (b). This pattern is duplicated with toluidine blue (c) and tryptase staining (d).

Membrane staining was identified in the epithelium of $82 \%$ of cases (Table 4). This comprised 11 fibroadenomas, six fibroadenomas with cellular stroma, 25 benign phyllodes, eight borderline phyllodes tumors, and three malignant phyllodes tumors. In the vast majority of positive tumors (51/53 cases), the percentage of positive cells was $>5 \%$ (in fact, well over $5 \%$ ), with large strips of epithelium or entire glands often staining for c-kit (results not shown). Epithelium was not present in six cases (one cellular fibroadenoma, one benign phyllodes, one borderline phyllodes, and three malignant phyllodes tumors), and of these, four cases (one cellular fibroadenoma, one benign phyllodes, one borderline phyllodes, and one malignant phyllodes tumor) were biopsies.

\section{Discussion}

Previous studies have suggested that $c$-kit is expressed in the stroma of phyllodes tumors. Some authors have observed this as a progressive increase in expression from benign to malignant tumors, ${ }^{17,19}$ while others have stated that $c$-kit tends to only be expressed in malignant phyllodes tumors. ${ }^{3,15,16}$ One study has also suggested that $c$-kit expression may be used as a predictor of recurrence. ${ }^{18}$

We detected a high number of cases $(74 \%)$ with some $c$-kit expression in the stroma. However, even in tumors that attained the greatest levels of expression, the positive cells rarely numbered more than $5 \%$ and were randomly scattered throughout the stroma. This pattern appears to be similar to that in the published photographs of two other studies. ${ }^{15,19}$ Secondly, when we performed toluidine blue and tryptase staining on our c-kit-positive cases, the pattern of the outlined cells closely resembled that seen with toluidine blue and tryptase (Figures 1 and 2). Hence, we conclude that the majority of stromal c-kit staining cells are in fact mast cells. Indeed, the presence of mast cells on corresponding H\&E slides of tumors in question could be verified. We used a monoclonal antibody with a high-dilution factor as well as a precise method of detection, which ensured a highly 

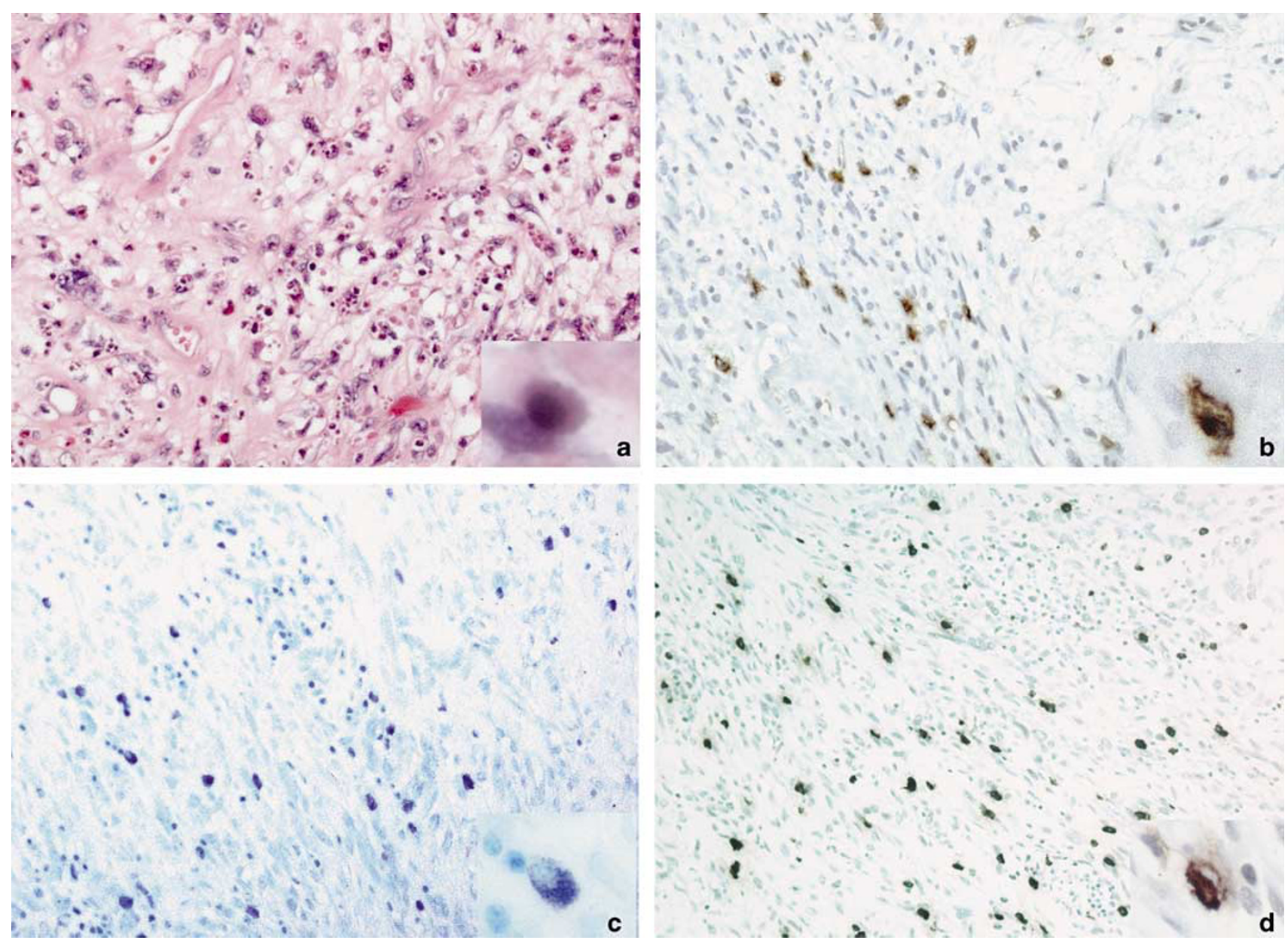

Figure 2 Malignant phyllodes tumor with mast cell infiltration of the stroma on H\&E (a). C-kit immunohistochemical staining reveals a pattern of scattered round to oval cells in the stroma (b). This pattern is duplicated with toluidine blue (c) and tryptase staining (d).
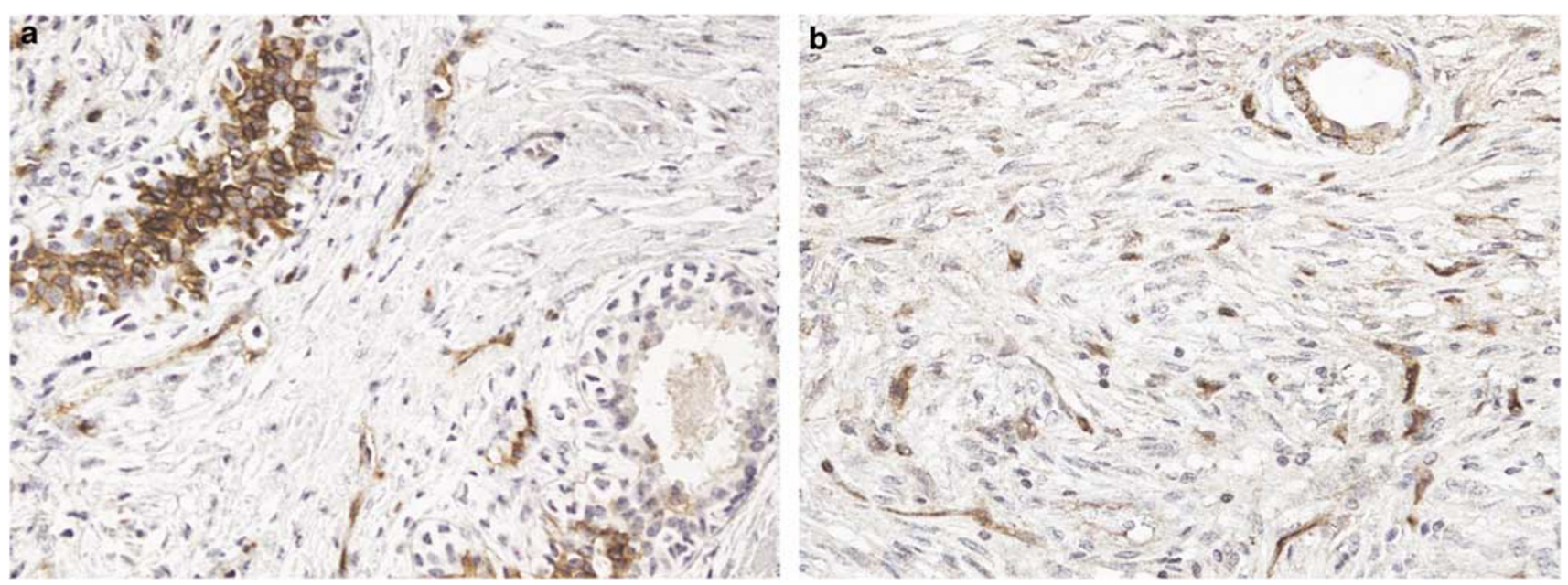

Figure 3 Borderline (a) and malignant (b) phyllodes tumor with faint diffuse immunostaining of elongated stromal cells for $c$-kit. Both tumors show no known activating mutations for $c$-kit or PDGFR $\alpha$.

specific immunoassay. This may be in contrast to some studies, where published photographs show significant background staining., ${ }^{3,16}$

Two of the cases in our study, one borderline phyllodes tumor and one malignant phyllodes tumor, displayed diffuse, but faint, stromal staining in elongated stromal cells (Figure 3). C-kit and PDGFR $\alpha$ mutational analysis for these tumors yielded negative results. Two past studies that detected stromal expression of $c$-kit sought to verify 
Table 4 Number and staining distribution of cases with an epithelial c-kit signal ( ${ }^{*}$ adjusted for cases with no epithelium (no epi) present)

\begin{tabular}{|c|c|c|c|c|c|c|}
\hline Tumor type & No epi & 0 & $<5 \%$ & $>5 \%$ & Total & $\begin{array}{c}\% \text { of all positive } \\
(<5 \% \text { and }>5 \%) \text { cases }\end{array}$ \\
\hline Fibroadenoma & 0 & 1 & 0 & 11 & 12 & $92 \%$ \\
\hline Cellular fibroadenoma & 1 & 2 & 0 & 6 & 9 & $75 \%$ \\
\hline Benign phyllodes & 1 & 4 & 2 & 23 & 30 & $86 \%$ \\
\hline Borderline phyllodes & 1 & 1 & 0 & 8 & 10 & $89 \%$ \\
\hline Malignant phyllodes & 3 & 1 & 0 & 3 & 7 & $75 \%$ \\
\hline Total & 6 & 9 & 2 & 51 & 68 & $82 \%$ \\
\hline
\end{tabular}

Table 5 Summary of studies addressing expression of stromal $c$-kit in phyllodes tumors

\begin{tabular}{|c|c|c|c|c|}
\hline Study & $\begin{array}{l}\text { c-kit expression in } \\
\text { stroma observed in }\end{array}$ & $\begin{array}{l}\text { Pattern of expression shown } \\
\text { in published photos }\end{array}$ & $\begin{array}{l}\text { Activating } \\
\text { mutations }\end{array}$ & Mast cells accounted for in the study \\
\hline Sawyer et $a l^{3}$ & $\begin{array}{l}1 / 20 \text { benign } \\
5 / 10 \text { malignant }\end{array}$ & Diffuse & None detected & No \\
\hline Carvalho et al ${ }^{15}$ & $\begin{array}{l}6 / 13 \text { benign } \\
6 / 6 \text { malignant }\end{array}$ & Focal subepithelial & None detected & $\begin{array}{l}\text { Yes-mast cells mentioned as internal } \\
\text { positive control for c-kit staining. Other } \\
\text { mast cell stains not performed. }\end{array}$ \\
\hline Chen et $a l^{16}$ & $\begin{array}{l}\text { 1/7 benign } \\
9 / 12 \text { malignant }\end{array}$ & Diffuse & $\begin{array}{l}\text { Analysis not } \\
\text { performed }\end{array}$ & No \\
\hline Esposito et $a l^{17}$ & $\begin{array}{l}\text { 2/16 benign } \\
5 / 18 \text { borderline } \\
4 / 6 \text { malignant }\end{array}$ & Photo not shown & $\begin{array}{l}\text { Analysis not } \\
\text { performed }\end{array}$ & No \\
\hline Tan et $a l^{18}$ & $\begin{array}{l}\text { 7/206 benign } \\
4 / 41 \text { borderline } \\
6 / 26 \text { malignant }\end{array}$ & $\begin{array}{l}\text { Tissue microarray study- } \\
\text { observation of pattern limited }\end{array}$ & $\begin{array}{l}\text { Analysis not } \\
\text { performed }\end{array}$ & $\begin{array}{l}\text { Yes-mast cells mentioned as internal } \\
\text { positive control for c-kit staining. Other } \\
\text { mast cell stains not performed. }\end{array}$ \\
\hline Tse et $a l^{19}$ & $\begin{array}{l}\text { 17/101 benign } \\
12 / 50 \text { borderline } \\
13 / 28 \text { malignant }\end{array}$ & Focal subepithelial & $\begin{array}{l}\text { Analysis not } \\
\text { performed }\end{array}$ & No \\
\hline Djordjevic et al & $\begin{array}{l}22 / 30 \text { benign } \\
7 / 10 \text { borderline } \\
6 / 7 \text { malignant }\end{array}$ & $\begin{array}{l}\text { Focal scattered (including } \\
\text { focal subepithelial) }\end{array}$ & None detected & $\begin{array}{l}\text { Yes-mast cells identified with } \\
\text { toluidine blue and tryptase. Number } \\
\text { and distribution corresponds to the c- } \\
\text { kit pattern-see Discussion. }\end{array}$ \\
\hline
\end{tabular}

their findings with mutational analyses, but, similarly, did not detect the presence of any activating

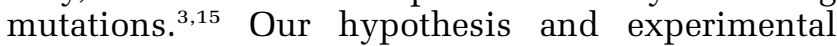
results provide an explanation for these findings.

Mast cell expression of $c$-kit is a well-established phenomenon ${ }^{27}$ and mast cell infiltration of solid tumors has been observed in both breast ${ }^{21,28,29}$ and non-breast neoplasms. ${ }^{30-33}$ In fact, in epithelial tumors of the breast, the presence of mast cells was associated with lower grade tumors ${ }^{29}$ and approached significance as an independent prognostic factor. ${ }^{21}$ In the context of phyllodes tumors, based on our observations, it would appear that this trend may be in the opposite direction (Table 3), with more malignant phyllodes tumors containing mast cells than their benign and borderline counterparts, and phyllodes tumors as a group more frequently containing mast cells than fibroadenomas (but less frequently than cellular fibroadenomas). This, interestingly, mirrors the findings of previous investigators who suggested that there is an increase in stromal $c$-kit expression from benign to malignant phyllodes tumors. ${ }^{17,19}$ However, without correlative patient outcomes, this aspect of our study is only a crude assessment, and no definitive conclusions on this phenomenon can be drawn without further investigation.

The more immediate significance of the mast cell findings in our project is the possibility that mast cell pattern either masks or mimics stromal-cell staining of c-kit in phyllodes tumors. On the basis of our observations, we propose that mast cells are either the predominant c-kit-staining cells in the stroma, or, if there are genuine c-kit-staining stromal cells, their numbers are negligible. Mast cells as internal positive control have been addressed in two ${ }^{15,18}$ out of $\operatorname{six}^{3,15-19}$ previous publications looking at stromal expression of $C$-kit in phyllodes tumors. However, these studies did not perform other mast cell-specific stains to differentiate relative levels of mast cells and genuine c-kit-staining stromal cells. The comparison of our and the other six studies is summarized in Table 5.

We believe that our study sheds light on a very important negative result. The apparent $c$-kit expression in the stromal component of phyllodes tumors is not substantiated by a molecular finding of any known activating mutations, and is likely a mast cell phenomenon. From this standpoint, c-kit has neither a diagnostic nor a prognostic role in 
phyllodes tumors, and there is no rationale for treatment of malignant or recurrent phyllodes tumor patients with tyrosine kinase inhibitors.

\section{Acknowledgements}

Contribution of cases: Dr Phoebe Shokry, Department of Pathology, Markham Stouffville Hospital, Markham, ON, Canada.

Histology and immunohistochemistry: Kevin Kwok and $\mathrm{Xu}$ Guo, Department of Pathology, Sunnybrook Health Sciences Center, Toronto, ON, Canada and Kelvin So, Department of Pathology, Pathology Research Program, University Health Network, Toronto, ON, Canada.

Statistical consultation: Marko Katic, Sunnybrook Health Sciences Center, Institute for Clinical Evaluative Sciences, Toronto, ON, Canada.

Mutational analysis: Xiaoduan Weng, $\mathrm{PhD}, \mathrm{MD}$, Hôpital Notre-Dame, CHUM, University of Montreal, Montreal, QC, Canada.

Administrative support: Karen Laws, Department of Pathology, Sunnybrook Health Sciences Center, Toronto, ON, Canada.

\section{Disclosure of interest}

The authors have no conflict of interest to declare.

\section{References}

1 Bellocq J, Magro G. Pathology and Genetics of Tumors of the Breast and Female Genital Organs, 1st edn. IARCPress: Lyon, 2003, pp432.

2 Yared MA, Middleton LP, Meric F, et al. Expression of c-kit proto-oncogene product in breast tissue. Breast J 2004;10:323-327.

3 Sawyer EJ, Poulsom R, Hunt FT, et al. Malignant phyllodes tumours show stromal overexpression of cmyc and c-kit. J Pathol 2003;200:59-64.

4 Tornillo L, Terracciano LM. An update on molecular genetics of gastrointestinal stromal tumours. J Clin Pathol 2006;59:557-563.

5 Allander SV, Nupponen NN, Ringner M, et al. Gastrointestinal stromal tumors with KIT mutations exhibit a remarkably homogeneous gene expression profile. Cancer Res 2001;61:8624-8628.

6 Andersson J, Sjogren H, Meis-Kindblom JM, et al. The complexity of KIT gene mutations and chromosome rearrangements and their clinical correlation in gastrointestinal stromal (pacemaker cell) tumors. Am J Pathol 2002;160:15-22.

7 Wang WL, Healy ME, Sattler M, et al. Growth inhibition and modulation of kinase pathways of small cell lung cancer cell lines by the novel tyrosine kinase inhibitor STI 571. Oncogene 2000;19:3521-3528.

8 Krystal GW, Honsawek S, Litz J, et al. The selective tyrosine kinase inhibitor STI571 inhibits small cell lung cancer growth. Clin Cancer Res 2000; 6:3319-3326.
9 O’Dwyer ME, Druker BJ. Chronic myelogenous leukaemia-new therapeutic principles. J Intern Med 2001;250:3-9.

10 Demetri GD, von Mehren M, Blanke CD, et al. Efficacy and safety of imatinib mesylate in advanced gastrointestinal stromal tumors. $\mathrm{N}$ Engl J Med 2002;347:472-480.

11 Tuveson DA, Willis NA, Jacks T, et al. STI571 inactivation of the gastrointestinal stromal tumor cKIT oncoprotein: biological and clinical implications. Oncogene 2001;20:5054-5058.

12 Verweij J, van Oosterom A, Blay JY, et al. Imatinib mesylate (STI-571 Glivec, Gleevec) is an active agent for gastrointestinal stromal tumours, but does not yield responses in other soft-tissue sarcomas that are unselected for a molecular target. Results from an EORTC Soft Tissue and Bone Sarcoma Group phase II study. Eur J Cancer 2003;39:2006-2011.

13 Medeiros F, Corless CL, Duensing A, et al. KIT-negative gastrointestinal stromal tumors: proof of concept and therapeutic implications. Am J Surg Pathol 2004;28:889-894.

14 Heinrich MC, Corless CL, Duensing A, et al. PDGFRA activating mutations in gastrointestinal stromal tumors. Science 2003;299:708-710.

15 Carvalho S, e Silva AO, Milanezi F, et al. c-KIT and PDGFRA in breast phyllodes tumours: overexpression without mutations? J Clin Pathol 2004;57:1075-1079.

16 Chen CM, Chen CJ, Chang CL, et al. CD34, CD117, and actin expression in phyllodes tumor of the breast. J Surg Res 2000;94:84-91.

17 Esposito NN, Mohan D, Brufsky A, et al. Phyllodes tumor: a clinicopathologic and immunohistochemical study of 30 cases. Arch Pathol Lab Med 2006;130:1516-1521.

18 Tan PH, Jayabaskar T, Yip G, et al. p53 and c-kit (CD117) protein expression as prognostic indicators in breast phyllodes tumors: a tissue microarray study. Mod Pathol 2005;18:1527-1534.

19 Tse GM, Putti TC, Lui PC, et al. Increased c-kit (CD117) expression in malignant mammary phyllodes tumors. Mod Pathol 2004;17:827-831.

20 Arber DA, Tamayo R, Weiss LM. Paraffin section detection of the c-kit gene product (CD117) in human tissues: value in the diagnosis of mast cell disorders. Hum Pathol 1998;29:498-504.

21 Dabiri S, Huntsman D, Makretsov N, et al. The presence of stromal mast cells identifies a subset of invasive breast cancers with a favorable prognosis. Mod Pathol 2004;17:690-695.

22 Hongxin F, Gulley ML. Molecular Pathology Protocols, 1st edn. Humana Press Inc: Totowa, NJ, 2001, pp1-3.

23 Lux ML, Rubin BP, Biase TL, et al. KIT extracellular and kinase domain mutations in gastrointestinal stromal tumors. Am J Pathol 2000;156:791-795.

24 Rubin BP, Singer S, Tsao C, et al. KIT activation is a ubiquitous feature of gastrointestinal stromal tumors. Cancer Res 2001;61:8118-8121.

25 Lasota J, Jasinski M, Sarlomo-Rikala M, et al. Mutations in exon 11 of c-Kit occur preferentially in malignant versus benign gastrointestinal stromal tumors and do not occur in leiomyomas or leiomyosarcomas. Am J Pathol 1999;154: 53-60.

26 Lasota J, Wozniak A, Sarlomo-Rikala M, et al. Mutations in exons 9 and 13 of KIT gene are rare events in 
gastrointestinal stromal tumors. A study of 200 cases. Am J Pathol 2000;157:1091-1095.

27 Baek JY, Tefferi A, Pardanani A, et al. Immunohistochemical studies of c-kit, transforming growth factorbeta, and basic fibroblast growth factor in mast cell disease. Leuk Res 2002;26:83-90.

28 Hussain MA, Tyagi SP, Tyagi N, et al. Stromal cellular response in breast tumours and allied lesions. J Indian Med Assoc 1992;90:119-121.

29 Amini RM, Aaltonen K, Nevanlinna H, et al. Mast cells and eosinophils in invasive breast carcinoma. BMC Cancer 2007;7:165.

30 Cabanillas-Saez A, Schalper JA, Nicovani SM, et al. Characterization of mast cells according to their content of tryptase and chymase in normal and neoplastic human uterine cervix. Int J Gynecol Cancer 2002;12:92-98.

31 Aoki M, Pawankar R, Niimi Y, et al. Mast cells in basal cell carcinoma express VEGF, IL-8 and RANTES. Int Arch Allergy Immunol 2003;130 216-223.

32 Shunyakov L, Ryan CK, Sahasrabudhe DM, et al. The influence of host response on colorectal cancer prognosis. Clin Colorectal Cancer 2004;4:38-45.

33 Junankar SR, Eichten A, Kramer A, et al. Analysis of immune cell infiltrates during squamous carcinoma development. J Investig Dermatol Symp Proc 2006;11:36-43. 